\title{
PEDAGOGOS DA SRE-OP: DESVELANDO O PERFIL, AS ESCOLHAS E A FORMAÇÃO DESSES PROFISSIONAIS
}

\author{
Nilzilene Imaculada Lucindo ${ }^{1}$, Regina Magna Bonifácio de Araújo ${ }^{2}$
}

\begin{abstract}
Resumo:
Este artigo resulta de uma pesquisa de Mestrado que buscou conhecer quem são os pedagogos que atuam nas instituições de ensino público da Superintendência Regional de Ensino de Ouro Preto. O estudo, de abordagem qualitativa, privilegiou a pesquisa documental, bibliográfica e de campo. Os dados foram coletados por questionário e entrevista e tratados pela análise de conteúdo. Identificamos que a escolha pela Pedagogia teve influência do curso de Magistério e que esses pedagogos são os especialistas de educação que se formaram na vigência do Parecer CFE n ${ }^{\circ}$ 252/69, quando o curso estava estruturado por habilitações. A formação inicial teve cunho mais teórico que prático, com pouco incentivo à pesquisa e, quanto à formação continuada, os pedagogos hoje se formam participando de cursos, congressos, pesquisando, trocando experiências com outros profissionais e participam, também, das formações ofertadas aos docentes, pois não há uma formação específica para esses sujeitos.
\end{abstract}

Palavras-chave: Curso de Pedagogia. Pedagogo. Perfil Profissional. Formação de Pedagogos.

1 Doutoranda em Educação pelo Programa de Pós-Graduação em Educação da Universidade Federal de Ouro Preto (UFOP). Mestra em Educação e Pedagoga pela UFOP. Docente do curso de Pedagogia da Faculdade de Educação / Campus BH / Universidade do Estado de Minas Gerais (UEMG). Membro do Grupo de Pesquisa Formação e Profissão Docente (FOPROFI) do Departamento de Educação da UFOP e do Núcleo de Estudos e Pesquisas de Psicologia da Educação e Psicopedagogia da UEMG.

E-mail: nilzilenelucindo@yahoo.com.br

2 Pós-Doutora em Educação pelo Instituto de Educação da Universidade de Lisboa - Portugal. Doutora em Educação pela Universidade Estadual de Campinas (UNICAMP). Mestra em Educação pela Universidade Federal de Juiz de Fora (UFJF). Professora titular - Adjunto IV do Departamento de Educação da Universidade Federal de Ouro Preto (UFOP), Coordenadora do Programa de Pós-Graduação em Educação da UFOP. Membro do Grupo de Pesquisa Formação e Profissão Docente (FOPROFI) do Departamento de Educação da UFOP e Coordenadora do Grupo de Estudos e Pesquisas em Educação de Jovens, Adultos e Idosos (GEPEJAI).

E-mail: regina.magna@hotmail.com 


\title{
TEACHERS FROM THE SRE-OP: UNVEILING THE PROFILES, CHOICES AND TRAINING OF THESE PROFESSIONALS
}

\author{
Nilzilene Imaculada Lucindo, Regina Magna Bonifácio de Araújo
}

\begin{abstract}
:
This article results from a Master's research that sought to know more about the teachers that work in the public schools of the Ouro Preto Regional Education Superintendence. The study, with a qualitative approach, focused on documentary, bibliographic and field research. Data were collected by questionnaire and interviews and processed by content analysis. We identified that the choice for teaching was influenced by the Magisterium course and that these teachers are the education specialists who were formed while "Parecer CFE No. 252/69" was in effect, when the course was structured around licenses. The initial education was more theoretical than practical, with little incentive to research and, as for continuing education, teachers today are qualified by attending courses, conventions, researching, exchanging experiences with other professionals and also participating in the training offered to teachers, since there is no specific training for these professionals.
\end{abstract}

Keywords: Education Degree. Teacher. Professional Profile.Teacher Education. 


\section{Introdução}

No Brasil, o curso de Pedagogia foi instituído há 79 anos, por meio do Decreto-Lei n ${ }^{\circ}$ 1190/39, e sua história demonstra que ele foi se constituindo repleto de questionamentos. No cerne deles, estavam a identidade, a finalidade, o currículo proposto, a dicotomia entre bacharelado e licenciatura, a fragmentação ocasionada pela instituição das habilitações, a base do curso centrada na docência ou na pedagogia, os reducionismos presentes em função da base estabelecida, a amplitude da formação oferecida, o perfil do profissional formado - pedagogo ou professor - e o campo de atuação dos egressos. Questionamentos que, ao longo dos anos, geraram discussões e foram contribuindo para lhe impor alterações.

Após a sua criação, o curso de Pedagogia foi modificado pelos Pareceres do Conselho Federal de Educação (CFE) no 251/62 e n 252/69 e pela Resolução do Conselho Nacional de Educação (CNE) n ${ }^{\circ} 1 / 2006$. As modificações originadas dessas normativas acarretaram mudanças no perfil e na formação dos egressos.

Diversos autores brasileiros (AGUIAR et al, 2006; AGUIAR; MELO, 2005; SILVA, 2006; 2011; CRUZ, 2009; EVANGELISTA; TRICHES, 2008; LIBÂNEO, 2007; 2011; LIBÂNEO; PIMENTA, 2011; SCHEIBE; AGUIAR, 1999; SCHEIBE, 2007) dedicaram-se a realizar pesquisas sobre o curso de Pedagogia e a formação do pedagogo. Essas temáticas também estiveram presentes nas discussões da Associação Nacional pela Formação dos Profissionais da Educação (ANFOPE), Associação Nacional de Pós-Graduação e Pesquisa em Educação (ANPED), Fórum Nacional de Diretores de Faculdades, Centro de Educação ou Equivalentes das Universidades Públicas Brasileiras (FORUMDIR) e Associação Nacional de Política e Administração da Educação (ANPAE). Trata-se de uma discussão antiga, mas que se traduz, ao mesmo tempo, em um debate bem contemporâneo e relevante, pois incide sobre um curso que hoje é responsável por formar os professores que atuarão na Educação Infantil e nos anos iniciais do Ensino Fundamental, bem como aqueles profissionais que farão a gestão do sistema educacional brasileiro.

Os dados que subsidiaram a elaboração deste artigo foram coletados para uma pesquisa de Mestrado desenvolvida no Programa de Pós-Graduação em Educação da Universidade Federal de Ouro Preto, que teve como objetivo geral conhecer quem são os pedagogos que atuam nas instituições de ensino público da Superintendência Regional de Ensino de Ouro Preto (SRE-OP). ${ }^{3}$

Esta investigação, de cunho qualitativo (BOGDAN; BIKLEN, 1994), adotou como procedimentos: a análise documental, que tomou como estudo a legislação que trata

3 De acordo com a Secretaria de Estado de Educação de MG, as Superintendências Regionais de Ensino - SRE têm por finalidade exercer, em nível regional, as ações de supervisão técnica e orientação normativa, de cooperação, articulação e integração entre Estado e Município, em consonância com as diretrizes e políticas educacionais. A SRE de Ouro Preto é composta pelos municípios de Acaiaca, Diogo de Vasconcelos, Itabirito, Mariana e Ouro Preto. 
do curso de Pedagogia no Brasil e normas correlatas; a pesquisa bibliográfica, que recorreu a artigos, dissertações e teses que tratam da temática investigada; e a pesquisa de campo. Na coleta de dados, foram utilizados dois instrumentos: o questionário e a entrevista semiestruturada. O questionário teve por finalidade levantar o perfil dos pedagogos e a entrevista procurou desvelar aspectos relativos às escolhas dos sujeitos pelo curso de Pedagogia e aos seus processos formativos, dentre outras questões. A entrevista foi estruturada em quatro categorias: Vida Pessoal; Vida Escolar; Processo Formativo; Atuação Profissional, sendo cada uma dessas categorias subdivididas em tópicos ou unidades de registro, conforme nomeia Bardin (2011). As categorias e as unidades de registro da entrevista foram previamente estabelecidas por temas, em função dos objetivos delimitados na pesquisa.

No tratamento dos dados, foi utilizada a técnica de análise de conteúdo (BARDIN, 2011). Logo, a análise deu-se a partir dos relatos dos pedagogos, tomando por base os elementos que emergiram desses relatos, e foi realizada em diálogo com o aporte teórico que sustentou a pesquisa, bem como da leitura de autores que tratavam das temáticas evidenciadas.

Os critérios adotados para a seleção dos pedagogos foram: o interesse em participar da pesquisa; a atuação em instituição de ensino público localizada em um dos cinco municípios que compõem a SRE-OP; possuir cargo efetivo e atuar ou já ter atuado no Ensino Fundamental. Optamos por trabalhar com o pedagogo que atua como coordenador pedagógico e não como docente ou diretor.

Justificamos nossa opção em trabalhar com o coordenador pedagógico por entender que o sujeito que está inserido na sala de aula - o professor - tem sido o objeto de estudo mais privilegiado das pesquisas da área de educação, disso decorrendo o interesse em dar voz aos pedagogos que atuam na coordenação pedagógica. Julgamos que, apesar de atuarem em outras áreas da escola, eles aguardam um momento para falarem, serem ouvidos e compartilharem suas histórias e experiências. Dar voz a esses sujeitos é trazer à tona questões relacionadas à cultura, à realidade e ao contexto que vivenciam, é permitir um mergulho para conhecer melhor as especificidades da profissão e da formação de pedagogo.

Este artigo tem por finalidade socializar os achados desta investigação, explicitando o perfil dos pedagogos que atuam nas instituições de ensino público da SRE-OP, as escolhas que os conduziram ao curso de Pedagogia, o seu processo de formação inicial e como ocorre a formação continuada no âmbito de sua atuação profissional.

\section{O curso de Pedagogia no Brasil em quatro marcos legais}

O Decreto-Lei no 1.190, de 04 de abril de 1939 (BRASIL, 1939) é o primeiro marco legal do curso de Pedagogia, entretanto, no período que antecede a sua aprovação, ocorreram debates sobre a criação das universidades brasileiras e reformas educacionais 
foram implementadas. Algumas dessas reformas se deram por iniciativa de Francisco Campos, Ministro da Educação e Saúde Pública, que defendeu a formação específica para professores do ensino secundário e recomendou a criação da Faculdade de Educação, Ciências e Letras. Os decretos nº 19.851 e 19.852 originaram-se na sua gestão.

O Decreto $\mathrm{n}^{\circ}$ 19.851, de 11 de abril de 1931 (BRASIL, 1931a), dispôs sobre o sistema universitário no Brasil e a organização técnica e administrativa das universidades e o Decreto n ${ }^{\circ} 19.852$ (BRASIL, 1931b) dispôs sobre a organização da Universidade do Rio de Janeiro. Conforme o artigo 196 do Decreto no 19.852, coube à Faculdade de Educação, Ciências e Letras, ministrar

o ensino superior de diversas disciplinas com os objetivos de ampliar a
cultura no domínio das ciências puras; de promover e facilitar a prática
de investigações originais; de desenvolver e especializar conhecimentos
necessários ao exercício do magistério; de sistematizar e aperfeiçoar,
enfim, a educação técnica e científica para o desempenho profícuo de
diversas atividades nacionais. (BRASIL, 1931b)

O artigo 199 organizou a Faculdade de Educação, Ciências e Letras nas seguintes seções: Educação; Letras; Ciências. A Seção de Educação compreendia as disciplinas consideradas fundamentais e de ensino obrigatório para os que pretendiam a licenciatura nas ciências da educação, sendo que a freqüência e a habilitação no curso da Faculdade de Educação confeririam o diploma de Licenciado em Educação, dando o direito de lecionar as ciências da Educação nos estabelecimentos de ensino secundário.

A Universidade do Rio de Janeiro, por meio do Decreto $\mathrm{n}^{\circ} 22.579$, de 27 de março de 1933 (BRASIL, 1933), serviu de modelo para a organização das universidades estaduais ou livres que não tinham seus estatutos aprovados. A Lei no 452, de 5 de julho de 1937 (BRASIL, 1937), organizou a Universidade do Brasil, que teria por finalidades essenciais:
a) o desenvolvimento da cultura filosófica, científica, literária e artística;
b) a formação de quadros donde se recrutem elementos destinados ao magistério bem como às altas funções da vida pública do país;
c) o preparo de profissionais para o exercício de atividades que demandem estudos superiores. (BRASIL, 1937)

Essa norma determinou que a Universidade do Brasil fosse a mantenedora de todos os cursos superiores previstos em lei. Nesse contexto, a Universidade do Rio de Janeiro foi transformada em Universidade do Brasil e é mediante a sua criação que surgem a Faculdade Nacional de Filosofia, Ciências e Letras e a Faculdade Nacional de Educação, que passam a responder pelos cursos de Filosofia, Ciências, Letras e 
Educação, sendo revogado o Decreto n ${ }^{\circ}$ 19.852, de 11 de abril de 1931.

De acordo com o Decreto-Lei n ${ }^{\circ}$ 1.190, a Faculdade Nacional de Filosofia, Ciências e Letras, que fora instituída pela Lei $n^{\circ}$ 452, de 5 de julho de 1937, foi unificada, passando a denominar-se Faculdade Nacional de Filosofia, tendo por finalidades:

\footnotetext{
a) preparar trabalhadores intelectuais para o exercício das altas atividades de ordem desinteressada ou técnica;

b) preparar candidatos ao magistério do ensino secundário e normal;

c) realizar pesquisas nos vários domínios da cultura, que constituam objeto de ensino. (BRASIL, 1939)
}

A Faculdade Nacional de Filosofia foi dividida em quatro seções: Filosofia, Ciências, Letras e Pedagogia. A essas quatro seções foi acrescentada uma seção especial de Didática. A seção de pedagogia foi constituída por apenas um curso: o de Pedagogia e, da mesma forma, constituiu-se a seção de Didática apenas pelo curso de didática. Nessa conjuntura, surgiu o curso de Pedagogia no Brasil, regulamentado pela primeira vez, nos termos do Decreto-Lei no 1.190/1939, que estabeleceu para o curso a duração de três anos e a seguinte distribuição de disciplinas por série:

\footnotetext{
a- $1^{\text {a }}$ série: Complementos de matemática; História da filosofia; Sociologia; Fundamentos biológicos da educação; Psicologia educacional;

b- $2^{\mathrm{a}}$ série: Estatística educacional; História da educação; Fundamentos sociológicos da educação; Psicologia educacional; Administração escolar;

c- $3^{\text {a }}$ série: História da educação; Psicologia educacional; Administração escolar; Educação comparada; Filosofia da educação. (BRASIL, 1939)
}

Aos concluintes do curso de Pedagogia seria conferido o diploma de Bacharel em Pedagogia. O curso de Didática, conforme definição do artigo 20, teria a duração de um ano e seria constituído das seguintes disciplinas: Didática geral; Didática especial; Psicologia educacional; Administração escolar; Fundamentos biológicos da educação; Fundamentos sociológicos da educação. Ao bacharel que concluísse o curso de didática seria conferido o diploma de licenciado no grupo de disciplinas que formaram o seu curso de bacharelado. Dessa forma, o diploma de licenciado em Pedagogia seria concedido ao graduando que tivesse concluído o Bacharelado em Pedagogia e o curso de Didática, estando ele habilitado para o exercício do magistério secundário e do curso Normal.

O Parecer do Conselho Federal de Educação (CFE), nº 251 (BRASIL, 1963), de autoria de Valnir Chagas, aprovado em 1962, constituiu o segundo marco legal. A resolução decorrente do Parecer 251 fixou o currículo mínimo do curso de Pedagogia 
e a sua duração, alterações que passaram a vigorar a partir de 1963. Valnir Chagas justificou que:

\begin{abstract}
A fixação de um currículo mínimo de Pedagogia tem a seu favor, como elemento de facilitação, a significativa concordância que já existe, no Brasil e no estrangeiro acerca do que deva constituir o núcleo de conhecimentos a exigir de um profissional de Educação preparado em nível superior. Se compararmos entre si os planos adotados em sistemas como os da França, da Inglaterra, dos Estados Unidos e da União Soviética, veremos que todos eles incluem uma parte comum e outra mais ou menos diversificada. (BRASIL, 1963, p.61)
\end{abstract}

Ao ser estabelecido, o currículo mínimo do curso de Pedagogia consistia em sete matérias para o bacharelado, a saber: Psicologia da Educação, Sociologia Geral e da Educação, História da Educação, Filosofia da Educação, Administração Escolar e as outras duas matérias seriam escolhidas a critério das instituições de ensino superior (IES).

Para os interessados no diploma que habilitava para o exercício do magistério no curso normal, Didática e Prática de Ensino eram disciplinas obrigatórias a serem cursadas. A duração do curso foi fixada em quatro anos, tanto para o bacharelado quanto para a licenciatura. Embora com uma nova regulamentação, o curso de Pedagogia manteve a configuração instituída pelo Decreto-Lei no 1.190/1939 e continuou formando profissionais para atuar como Técnico de Educação e Professor das matérias pedagógicas do curso Normal.

O terceiro marco legal do curso, o Parecer do CFE, n 252, de 11 de abril de 1969, de autoria de Valnir Chagas, também fixou “os mínimos de conteúdo e duração a serem observados na organização do curso de Pedagogia” (BRASIL, 1969, p.113). A promulgação da Lei $n^{\circ}$ 5.540/68 (BRASIL, 1968) pode explicar muitas das alterações impostas ao curso de Pedagogia por meio do Parecer n 252/69. Isso pode ser observado quando o relator menciona em seu texto o artigo 23 dessa lei, dispondo que: “os cursos profissionais poderão, segundo a área abrangida, apresentar modalidades diferentes quanto ao número e à duração, a fim de corresponder às condições do mercado de trabalho.” (BRASIL, 1968, p. 4) A regulamentação proposta no Parecer n 252/69 instituiu as habilitações para a formação de especialistas em Orientação Educacional, Administração Escolar, Supervisão Escolar e Inspeção Escolar. O bacharelado foi extinto e o curso passou a conferir aos concluintes apenas o título de Licenciado em Pedagogia, definindo ainda que os especialistas atuariam no âmbito das escolas e sistemas escolares. A formação do especialista em Planejamento Educacional seria obtida com o Mestrado.

Ao instituir as habilitações, Valnir Chagas (BRASIL, 1969, p. 107) destaca que "a distinção feita prende-se tão somente às exigências imediatas do mercado de trabalho” 
e "que todas elas, resultando de curso único, devem supor um só diploma: o de bacharel.” (BRASIL, 1969, p. 109), porém, ao ser apreciado, o Plenário, adotando a ideia de um só diploma, acolheu a emenda apresentada pelo Conselheiro D. Luciano Duarte e fixou o título único de Licenciado. Nesse sentido, atendendo ao disposto na Lei ${ }^{0} 5.540 / 68$ e no parecer $n^{\circ} 252 / 69$, ficou decretado que

A formação de professores para o ensino normal e de especialistas para
as atividades de orientação, administração, supervisão e inspeção, no
âmbito de escolas e sistemas escolares, será feita no curso de graduação
em Pedagogia, de que resultará o grau de licenciado com modalidades
diversas de habilitação. (BRASIL, 1969, p.113)

Na proposta implementada, o currículo terá uma parte comum e outra diversificada, em função das habilitações. A Didática que, pelo Decreto-Lei no 1.190/1939, se constituía como um curso à parte, foi transformada em uma disciplina obrigatória do curso. Assim, da referida relação de matérias, foram determinadas, no artigo $3^{\circ}$ do Parecer, aquelas que deveriam ser cursadas para cada uma das habilitações, junto com as disciplinas obrigatórias que compõem a parte comum. A carga horária e a duração mínima do curso também variavam em função da habilitação. O parecer instituiu a obrigatoriedade do estágio às várias habilitações e a exigência de experiência de magistério para as habilitações de Orientação Educacional, Administração e Supervisão Escolar. Os portadores do diploma do curso de Pedagogia estavam habilitados para:

a) o exercício das atividades relativas às habilitações registradas em cada caso;

b) o exercício de magistério, no ensino normal, das disciplinas correspondentes às habilitações específicas e à parte comum do curso ( $\S 1^{\circ}$ do art. $2^{\circ}$, letras $b$ e $f$ ) quando este tiver duração igual ou superior a duas mil e duzentas horas, observados os limites estabelecidos para efeito de registro profissional;

c) o exercício de magistério na escola de $1^{\circ}$ grau, na hipótese do número 5 (cinco) do artigo $3^{\circ}$ e sempre que haja sido estudada a respectiva metodologia e prática de ensino. (BRASIL, 1969, p.116)

O diploma do concluinte desse curso terá uma ou duas habilitações, podendo o licenciado complementar seus estudos adquirindo novas habilitações. As habilitações também eram abertas aos egressos de outros cursos, desde que, ao complementarem o estudo, cumprissem uma carga horária mínima de 1100 horas.

O Parecer CFE nº 252/69 já vigorava há 27 anos, até que foi aprovada a Lei de Diretrizes e Bases da Educação (LDB) no 9.394, em 20 de dezembro de 1996 (BRASIL, 1996), que propôs a formação dos profissionais da educação em nível superior e recriou os Institutos Superiores de Educação, instituindo um novo espaço 
de formação e também um novo curso para formar esses profissionais - o Normal Superior. Ao mesmo tempo, em seu artigo 64, a LDB delegou aos cursos de Pedagogia a responsabilidade pela formação dos especialistas em educação. Essas deliberações contribuíram para acirrar os debates acerca do curso, resultando na Resolução CNE/ $\mathrm{CP}^{\circ}{ }^{0}$, de 15 de maio de 2006 (BRASIL, 2006a).

Com a aprovação da nova LDB, medidas foram tomadas com vistas à reforma curricular dos cursos de graduação. Em 1997, a Secretaria de Ensino Superior do Ministério da Educação (SESU/MEC), tornou público e convocou as IES a apresentarem propostas para as novas Diretrizes Curriculares dos cursos superiores, as quais seriam elaboradas pelas Comissões de Especialistas da SESU/MEC. Começava, então, uma longa trajetória de debates acerca da institucionalização das diretrizes curriculares para o curso de Pedagogia.

Nomeada por meio de portaria, a primeira Comissão de Especialistas do Ensino de Pedagogia (CEEP), com mandato de 2 anos, apresentou ao Conselho Nacional de Educação (CNE), em maio de 1999 uma proposta que, segundo Scheibe (2007), considerou as sugestões oriundas das entidades educacionais que participaram das discussões relativas à reformulação dos cursos de formação. No documento elaborado, observou-se uma visão bastante alargada do pedagogo, pois ele poderia atuar como docente na Educação Infantil, nos Anos Iniciais do Ensino Fundamental, no Ensino Normal, na organização e gestão de sistemas, em projetos educacionais e em diversas áreas da educação, entretanto, o documento não foi apreciado pelo CNE.

Mediante o exposto, a portaria anterior foi revogada e nova comissão foi instituída, a qual elaborou uma proposta que reiterava a anterior, elaborada pela CEEP, instituída em 1999. Essa proposta defendia que a base da formação do pedagogo seria a docência e que o curso deveria ser de graduação e, pela sua natureza, seria, ao mesmo tempo, uma licenciatura e um bacharelado. $\mathrm{O}$ documento elaborado pela segunda Comissão foi encaminhado ao CNE, em fevereiro de 2001, mas também não foi homologado. Assim, em 2002, o governo pôs fim ao trabalho das comissões e o CNE designou uma Comissão Bicameral, constituída por membros da Câmara de Educação Superior e da Câmara de Educação Básica, para definir as diretrizes curriculares nacionais para o curso. Essa seria a terceira comissão a elaborar as diretrizes para o curso de Pedagogia.

Em maio de 2004, em função da renovação dos membros do CNE, a Comissão Bicameral foi recomposta. Em 17 de março de 2005, o CNE divulgou, para apreciação da sociedade civil, a minuta do Projeto das Diretrizes Curriculares Nacionais para o curso de Pedagogia, o que causou inúmeras discussões, visto que o curso ficou restrito à formação para docência na Educação Infantil e Séries Iniciais do Ensino Fundamental. A minuta, rejeitada pela comunidade acadêmica, desencadeou uma nova mobilização por parte dos educadores, principalmente, pela ANFOPE, que sintetizou tais manifestações em um documento e, assinando-o conjuntamente com 
a ANPED e o CEDES, enviou-o ao CNE solicitando uma audiência pública antes da aprovação das diretrizes.

Diante da pressão do movimento de educadores, uma comissão do CNE elaborou um novo parecer, o Parecer CNE/CP n ${ }^{\circ}$ 5/2005 (BRASIL, 2005) e a Resolução que o acompanha, sobre as diretrizes curriculares nacionais para o curso de Pedagogia. Esse Parecer, considerando algumas das solicitações do movimento, foi aprovado em 13 de dezembro de 2005. De acordo com o parecer,

O curso de Licenciatura em Pedagogia destina-se à formação de professores para exercer funções de magistério na Educação Infantil e nos anos iniciais do Ensino Fundamental, nos cursos de Ensino Médio, na modalidade Normal, de Educação Profissional na área de serviços e apoio escolar e em outras áreas nas quais sejam previstos conhecimentos pedagógicos. As atividades docentes também compreendem participação na organização e gestão de sistemas e instituições de ensino, englobando: - planejamento, execução, coordenação, acompanhamento e avaliação de tarefas próprias do setor da Educação; - planejamento, execução, coordenação, acompanhamento e avaliação de projetos e experiências educativas não escolares; - produção e difusão do conhecimento científico-tecnológico do campo educacional, em contextos escolares e não escolares. (BRASIL, 2005, p.7-8)

Embora aprovado por unanimidade no Conselho Pleno do CNE, o Conselheiro César Callegari, apontou para a divergência entre o artigo 14 da Resolução e o artigo 64 da LDB no 9394/96. Por essa razão, o MEC reencaminhou o processo ao CNE solicitando reexame da matéria, o que resultou na elaboração do Parecer CNE/CP n ${ }^{\circ}$ 3/2006 (BRASIL, 2006b). Segundo consta no Parecer CNE/CP nº 3/2006, a Comissão Bicameral de Formação de Professores revisou minuciosamente o texto do Projeto de Resolução contido no Parecer CNE/CP n ${ }^{\circ}$ 5/2005 e as disposições legais vigentes. Após essa revisão, propôs uma ementa retificando o artigo 14 da resolução anexa ao Parecer CNE/CP n ${ }^{\circ}$ 5/2005, a qual segue explicitada abaixo:

Art. 14. A Licenciatura em Pedagogia nos termos do Parecer CNE/CP $n^{\circ}$ 5/2005 e desta Resolução assegura a formação de profissionais da educação prevista no art. 64, em conformidade com o inciso VIII do art. $3^{\circ}$ da Lei $n^{\circ}$ 9.394/96.

$\S 1^{\circ}$. Esta formação profissional também poderá ser realizada em cursos de pós-graduação, especialmente estruturados para este fim e abertos a todos os licenciados.

$\S 2^{\circ}$. Os cursos de pós-graduação indicados no $\S 1^{\circ}$ deste artigo poderão ser complementarmente disciplinados pelos respectivos sistemas de ensino, nos termos do Parágrafo único do art. 67 da Lei no 9.394/96. (BRASIL, 2006a, p.2) 
A Comissão considerou que a redação supracitada não deixava dúvidas sobre o que dispunha o artigo 64 da LDB, bem como garantia que a Licenciatura em Pedagogia realizaria a formação para administração, planejamento, inspeção, supervisão e orientação educacional em organizações (escolas e órgãos dos sistemas de ensino) da Educação Básica e também esclareceu as condições em que a pós-graduação deveria ser realizada. Assim, a Comissão foi favorável ao encaminhamento do Projeto de Resolução contido no Parecer CNE/CP n ${ }^{0}$ 5/2005, com a nova redação do artigo 14 para aprovação. Dessa forma, o Conselho Pleno aprovou o voto da Comissão e a Resolução CNE/CP n ${ }^{\circ} 1 / 2006$, que fixa as novas diretrizes curriculares para o curso de Pedagogia, foi aprovada em 15 de maio de 2006, tornando-se o quarto marco legal do curso.

\section{Discussões acerca da história do curso de Pedagogia no Brasil}

Ao olharmos para a história do curso, observamos que cada uma dessas modificações sofridas colaborou para o surgimento e a manutenção de dicotomias que, historicamente, circundaram o curso de Pedagogia.

Scheibe e Durli (2011, p. 86) ressaltam que, ao ser criado, “[...] o curso de Pedagogia atendeu aos ditames de uma proposta universitária profissionalizante”. Scheibe e Aguiar (1999) e Castro (2007) entendem que o curso de Pedagogia no Brasil é fruto da preocupação com a formação de professores que atuam no Ensino Normal. O Decreto-lei n ${ }^{\circ} 1.190 / 39$, em seu artigo $1^{\circ}$, ao estabelecer as finalidades da Faculdade Nacional de Filosofia, declara ser uma delas "preparar candidatos ao magistério do ensino secundário e normal”. Dessa forma, percebemos que o curso de Pedagogia é criado com o propósito de formar professores, contudo, pela organização imposta e a que ele estava submetido, primeiro ele formava o bacharel em três anos que, para se tornar professor, necessitava frequentar um segundo curso, o de Didática, com a duração de um ano. Tratava-se, na verdade, de dois cursos distintos, "[...] o 'curso de Pedagogia', como bacharelado, e o 'curso de didática', como licenciatura a ser oferecido após aquele [...]” (SILVA, 2011, p.142).

Mediante a disposição proposta no currículo dos cursos que compunham as quatro seções da Faculdade Nacional de Filosofia, provavelmente, não se poderia dizer que esses cursos tiveram suas bases estabelecidas na docência, uma vez que o bacharelado prevalece em detrimento da docência, que acabou tornando-se secundária ao ser desenvolvida posteriormente, como uma forma de complementação pedagógica, em curso específico. Não se podia ser um licenciado sem antes se tornar um bacharel. Tendo em vista a organização estabelecida pelo Decreto-Lei no 1.190/39, fica explícito que a formação do pedagogo, nesse período, foi caracterizada pela separação entre bacharelado e licenciatura, "[...] refletindo a nítida concepção dicotômica que orientava o tratamento de dois componentes do processo pedagógico: o conteúdo e o método”, conforme apontam Pinheiro e Romanowski (2010, p.146). 
Acerca da identidade do curso na vigência do Decreto-Lei no 1.190/39, Scheibe e Durli (2011, p.100) registram que:

Primeiro, ele serviu para formar os dirigentes educacionais do país, assim como os professores para os cursos normais de ensino médio que formavam os profissionais para a escolarização fundamental. O curso tinha esta identidade: pedagogo era o professor dos cursos normais e/ ou o técnico em assuntos educacionais.

Quanto ao campo de atuação dos egressos, não havia clareza sobre o locus de atuação desses profissionais. O mais certo é que atuariam como docentes no Ensino Normal, havendo também a possibilidade de atuarem como Técnico em Educação, no Ministério da Educação, sendo que esse último locus só foi definido a partir de 1943, quando se instituiu a obrigatoriedade do diploma de Bacharel em Pedagogia para ocupar os cargos nessa instituição. Devido à indefinição quanto às funções que o profissional poderia exercer e pelo fato de a Licenciatura não ser um campo exclusivo dos pedagogos, ainda foi concedido, ao Licenciado em Pedagogia, o direito de lecionar filosofia, história e matemática (SILVA, 2006; SAVIANI, 2008; LEITE; LIMA, 2010).

Durante 23 anos, o curso de Pedagogia manteve-se sem alteração e em conformidade com a configuração inicial proposta na sua criação. A principal alteração introduzida pelo Parecer CFE nº 251/62 está relacionada com a composição curricular do curso e sua duração.

Ao ser aprovado, o Parecer CFE n ${ }^{\circ}$ 251/62 alterou apenas o currículo, estabelecendo uma base comum e outra diversificada e a duração do curso em quatro anos. Da forma como o currículo estava sendo proposto, Valnir Chagas deixa claro que "ensejava a preparação de um bacharel realmente ajustável a tôdas [sic] as tarefas não-docentes da atividade educacional [...]" (BRASIL, 1963, p.64). A alteração que passou a vigorar a partir de 1963 representou, na opinião de Silva (2006), uma clareza acerca da provisoriedade atribuída ao curso de Pedagogia. Assim, “a partir de 1962, o curso de Pedagogia (grifo da autora) passa a assumir a formação de ambos, tanto a do 'técnico em educação' quanto a do 'professor' de disciplinas pedagógicas do curso normal” (SILVA, 2011, p. 137), conferindo o caráter generalista ao curso, tal como descrevem Saviani (2004) e Castro (2007).

No entendimento de Silva (2011, p.142), o que houve foi uma tentativa de estabelecer "a concomitância entre o bacharelado e a licenciatura nos cursos em geral, inclusive no de pedagogia.” Nesse novo cenário, “a licenciatura, a partir daí, não mais se configurou como um 'curso de didática', embora continuasse a compreender um elenco de disciplinas em separado às do bacharelado.” (SILVA, 2011, p.142) Para essa autora, ao ser proposto um currículo mínimo, no qual é possível optar por duas disciplinas e, no elenco dessas opcionais, figuram disciplinas mais voltadas para as atividades profissionais, "pode-se observar que já se verificava aqui a transição para 
a introdução da segunda versão - a do especialista.” (SILVA, 2011, p.145)

O Parecer CFE nº 252/69 reorganizou o curso de Pedagogia e, junto à habilitação, já existente, de formação de professor para atuar no Ensino Normal, foram introduzidas as habilitações de supervisão, orientação, administração e inspeção escolar, fato que levou a identidade do pedagogo a ser a do especialista ou, como explicita Brzezinski (2011, p. 126), “pedagogo especialista: identidade tecnicista”. Na estrutura do currículo proposto, a parte comum composta pelos fundamentos da educação, era considerada necessária a qualquer profissional da área de educação; a parte diversificada estruturavase para atender às habilitações que seriam conferidas aos licenciados.

Lima (2004) destaca que, na vigência dos pareceres anteriores, a fragmentação no curso de Pedagogia já se configurava pela separação entre bacharelado e licenciatura. Ao passo que, na vigência do Parecer CFE nº 252/69, o caráter fragmentado do curso deu-se em função da institucionalização das habilitações pelas quais o pedagogo se tornava um Especialista. Lima (2004, p.17) revela que "fragmentava-se a realidade escolar segundo as funções a serem desempenhadas: docência, administração, supervisão, orientação educacional, inspeção escolar, entre outras.”

Na concepção de Libâneo e Pimenta (2011), o parecer foi claro ao estabelecer para o curso a função de formar professores para atuarem no Ensino Normal e os especialistas (orientador, supervisor, administrador e inspetor) para atuarem em funções específicas nas escolas e no sistema escolar, além de conceder, parcialmente, a atuação do licenciado nas séries iniciais no ensino primário. A instituição das habilitações ainda representou uma forma de definir o "exercício profissional do pedagogo não-docente" (LIBÂNEO; PIMENTA, 2011, p.22). Ambos os autores entendem que o Parecer CFE $n^{\circ}$ 252/69 foi o que melhor determinou a natureza de um curso de Pedagogia, apesar de ter sido intensamente criticado.

Libâneo e Pimenta (2011, p.23) reconhecem essa fragmentação do curso, contudo, afirmam que "não nos parece problemática hoje a ênfase que o Parecer deu à formação de técnicos de educação nem ao reconhecimento de tarefas específicas a serem realizadas nas escolas para acompanhamento do ensino.” Na visão desses autores, resultavam problemáticos:

(a) o caráter "tecnicista" do curso e o consequente esvaziamento teórico da formação, excluindo o caráter da Pedagogia como investigação do fenômeno educativo; (b) o agigantamento da estrutura curricular que leva ao mesmo tempo a um currículo fragmentado e aligeirado; (c) a fragmentação excessiva de tarefas no âmbito das escolas; (d) a separação no currículo entre os dois blocos, a formação pedagógica de base e os estudos correspondentes às habilitações. (LIBÂNEO; PIMENTA, 2011, p.24-25)

O cenário estabelecido na vigência do Parecer CFE nº 252/69, segundo Libâneo 
(2007), influenciou a defesa do movimento em prol de um curso voltado para a formação de professores e da extinção das habilitações. Isso fez com que o curso de Pedagogia fosse desconfigurado e reduzido apenas à docência, a partir da aprovação de sua nova regulamentação, a Resolução CNE/CP nº 01/2006, instituída em 15 de maio de 2006.

As atuais diretrizes definiram a docência como base da formação do pedagogo, que também irá se tornar a base de sua identidade profissional. O curso foi definido como uma licenciatura cuja finalidade é a formação do professor para atuar na educação infantil e nas séries iniciais, todavia, apresenta uma ampliação do conceito de docência que, na visão de Aguiar et al (2006, p.830), não é o de apenas dar aulas, "uma vez que se articula à ideia de trabalho pedagógico, a ser desenvolvido em espaços escolares e não-escolares [...]”.

Para Aguiar e Melo (2005, p.120), "as interpretações diferenciadas sobre a Pedagogia têm resultado historicamente em vários reducionismos e abrangências, bem como em diversas identidades concernentes ao curso de Pedagogia no Brasil.” Embora o curso apresente a docência como base de sua formação, o estudo da Pedagogia não pode ser relegado a um segundo plano, justamente, por possuir uma dimensão que está além da docência e não o contrário, levando à ideia de que é a docência que está além da Pedagogia.

Ao estabelecer a docência como a base do curso de Pedagogia e ao abrir um leque amplo de formação, a discussão volta-se para essa amplitude oferecida e se o currículo tem garantido, de fato, a formação do professor para atuar na Educação Infantil e nos anos iniciais do Ensino Fundamental, além da gestão. Pesquisas que avaliem a formação ofertada sob a égide da atual diretriz que regula o curso poderão indicar como tem sido realizada a formação de pedagogos na contemporaneidade.

Os dados apresentados a seguir ilustram o perfil profissional e a formação inicial, dentre outros aspectos, de pedagogos que se graduaram na vigência do Parecer CFE $n^{\circ} 252 / 69$.

\section{Os pedagogos que atuam nas instituições de ensino público da SRE-OP}

\section{Perfil profissional}

Os estudos de Libâneo (2011) e de Franco, Libâneo e Pimenta (2007), que tratam da pedagogia, também caracterizam o pedagogo. Na concepção desses autores, o pedagogo, profissional graduado no curso de Pedagogia, é aquele "[...] que cuida da formação humana em todos os lugares em que essa formação acontece de forma intencional e sistemática.” (FRANCO; LIBÂNEO; PIMENTA, 2007, p.89). O pedagogo é, ainda,

o profissional que atua em várias instâncias da prática educativa, direta ou indiretamente ligadas à organização e aos processos de transmissão e assimilação de saberes e modos de ação, tendo em vista objetivos 
de formação humana previamente definidos em sua contextualização histórica. (LIBÂNEO, 2011, p.72)

O grupo de entrevistados foi composto por quatorze mulheres e um homem que concluíram a graduação em Pedagogia entre os anos de 1983 e 2010, na vigência do Parecer $n^{\circ}$ 252/69 e obtiveram o título de Licenciado de Pedagogia. As habilitações mais cursadas foram a Supervisão Pedagógica e o Magistério das Matérias Pedagógicas.

Conforme apontaram os dados, o número de mulheres atuando nessa profissão sobressai ao do sexo oposto, reafirmando o Magistério como uma profissão feminina. Esse dado, que ressalta a presença maciça da mulher nos cursos de licenciatura e de Pedagogia, também foi destacado por Gatti e Barretto (2009). "Ser professora" constitui uma opção para mulheres, mas o desejo de "ser professor" foi o motivo que levou o sujeito do sexo masculino a ingressar no curso.

Eles atuam em escolas públicas nos municípios de Itabirito, Mariana e Ouro Preto, em MG. Não integraram o grupo os profissionais de Acaiaca e Diogo de Vasconcelos, visto que, dos sete sujeitos identificados em ambas as cidades, dois não se interessaram em participar, um não possuía vínculo efetivo e os demais são licenciados em outras áreas com Pós-Graduação em Supervisão Escolar, retratando a realidade estabelecida pelo artigo 64 da LDB n ${ }^{\circ}$ 9394/96, que trata da formação dos profissionais da educação.

Dos quinze entrevistados, cinco atuam na rede estadual e dez na rede municipal de ensino, porém, ocupam cargos distintos, estabelecidos pelo curso ou pela rede de ensino em que atuam: oito são supervisores pedagógicos; dois são orientadores educacionais e cinco pedagogos, o que explicita a multiplicidade de denominações atribuídas aos profissionais formados por esse curso.

Os entrevistados possuem experiência nas funções de docente (12); diretor (6); e vice-diretor (1). Onze possuem habilitação em Magistério de $1^{\circ}$ grau e um cursou o Magistério de $1^{\circ}$ grau, obtendo a habilitação para atuar com Educação Física, da $1^{\mathrm{a}}$ à $6^{a}$ série, conforme o artigo 30 da Lei no 5692/71 (BRASIL, 1971).

Em relação ao locus de conclusão da graduação, sete sujeitos concluíram seu curso em Universidades, quatro em Institutos de Educação e os demais em Faculdades isoladas. Scheibe e Aguiar (1999) chamam a atenção para a distinção existente entre universidades de pesquisa e universidades de ensino e o lugar onde se desenvolverá a formação docente: o menos oneroso. O locus onde o pedagogo concluiu seu curso irá influenciar a sua formação, principalmente no que concerne à questão da indissociabilidade entre ensino, pesquisa e extensão, uma exigência das universidades.

Doze pedagogos possuem Especialização Lato Sensu e um desses, além da Especialização, possui o Mestrado em Pedagogia. A maior parte cursou Especialização em Psicopedagogia. 


\title{
As escolhas
}

A escolha por uma profissão não se realiza aleatoriamente e está sujeita à influência de diversos aspectos. Para Saraiva e Ferenc (2010, p.4), “a origem social e cultural dos sujeitos torna-se, dessa forma, um elemento esclarecedor de suas trajetórias escolares.” Os sujeitos ingressaram na Pedagogia: “por falta de opção; por opção, por gostar; por influência do Magistério; por influência da família; por influência de professores; por influência da catequese; por exigência da LDB. n 9394/96; por interesse próprio; pelas habilitações ofertadas no curso; pelo aprimoramento; por influência de colegas; por compreender a finalidade da educação; para dar aulas.”

As respostas mais explicitadas foram por influência do Magistério (7), por influência de professores (6); por influência da família, por interesse próprio e por falta de opção (4). O excerto abaixo ilustra uma dessas respostas:

\begin{abstract}
[...] na verdade, era algo que eu sempre, no fundo eu sempre quis. Eu lembro que na época, quando eu tive que escolher o curso, eu fiquei entre dois cursos. O de Psicologia e o de Pedagogia. E no final acabou pesando Pedagogia, porque eu pensei assim, bom, eu já fiz Magistério, dentro de Pedagogia eu vou ver Psicologia e era uma das matérias que eu mais gostava no curso de Magistério. [...] sempre foi uma área que eu quis atuar que era a área da Educação, então eu acho que a motivação para fazer Pedagogia começou aí, desde o curso de Magistério (Pedagogo 5).
\end{abstract}

O Magistério foi o fator que mais influenciou a escolha pela Pedagogia, já que a maioria (12) ingressou primeiro nesse curso. É como se o curso de Magistério indicasse qual direção seguir e o de Pedagogia confirmasse a decisão que foi tomada, tal como descreve Cruz (2011), ao salientar a proximidade existente entre os dois cursos. Dentre as razões que conduzem os estudantes a escolherem a licenciatura, citadas por Gatti e Barretto (2009, p.159), algumas são semelhantes às desta pesquisa: "Porque quero ser professor; Por influência da família; Porque tive um bom professor que me serviu de modelo.” A possibilidade de atuação na docência foi um aspecto evidenciado nesta pesquisa e destacado no estudo de Saraiva e Ferenc (2010).

Os pedagogos demonstraram satisfação com a escolha realizada e quatorze deles afirmaram que optariam novamente por essa profissão, como expôs o Pedagogo 4: "Se eu fosse escolher? Eu escolheria Pedagogia, não tenho dúvida. E, assim, acho que a mesma instituição que eu formei porque me deu uma boa base. [...] Pedagogia, com certeza, eu não faria outra coisa, eu não consigo me imaginar."

\section{A formação inicial}

Os dados que explicitam a formação vivenciada na graduação trazem à tona informações alusivas às metodologias utilizadas pelos formadores; ao contato com 
a Educação Básica; ao estágio; à pesquisa; aos pontos fortes e às lacunas do curso.

Os relatos indicaram que as metodologias mais adotadas pelos professores formadores eram as aulas expositivas, os trabalhos em grupos e individuais e os seminários, o que coincide com os dados já apresentados por Gatti e Barretto (2009). Essas autoras revelam que as estratégias mais utilizadas pelos professores são as aulas expositivas, sobressaindo-se, também, "a utilização de trabalhos em grupo na sala de aula." (GATTI; BARRETTO, 2009, p.174)

Era aula expositiva, tinha trabalhos de grupo, mas era assim, aula expositiva e trabalhos de grupo, estudo individual. O que eu me lembro era bem isso. Não tinha assim, tanto seminários, fóruns, oficinas. [...] Tinha trabalho individual e trabalho em grupo e aula expositiva. Não tinha tantos recursos, a gente não tinha internet, nem tinha computador na época que eu estudava, nem sabia mexer, então assim, era o mais tradicional (Pedagogo 1).

Acho que o mais forte era a exposição, mas nós tínhamos debates, trabalhos de grupo nós tínhamos também e todo sábado, que a nossa aula era de segunda a sábado, nós tínhamos seminários. O período da tarde eram seminários, tanto com a nossa atuação muito forte ou também momentos em que a gente ouvia muitas experiências, naquele momento, de pessoas que já atuavam. (Pedagogo 2)

Nos depoimentos, surgem outras metodologias, como debates, mesa redonda, teatro, filmes, atividades com jogos, relatos de experiências, visitas técnicas, observação da prática e leitura dos clássicos da educação, porém, segundo oito entrevistados, o curso teve um cunho mais teórico, o que demonstra o comprometimento da relação teoria e prática, e constitui uma preocupação para Gatti e Barretto (2009). A pesquisa evidencia uma preocupação do curso com as disciplinas teóricas, o que também já foi destacado por Cruz (2009), ao ressaltar as características do curso de Pedagogia. Segundo os entrevistados, as práticas estavam mais associadas às disciplinas de Metodologia.

O contato do licenciando com a Educação Básica, para cinco entrevistados, deu-se apenas no estágio, contudo, para os demais, esse contato foi viabilizado em outros momentos, por meio da extensão e monitoria, ao desenvolverem trabalhos extraclasses além de, neste caso, poder considerar a vivência dos alunos que cursaram o Magistério e dos licenciandos que já lecionavam:

No curso ele se deu mais através desta experiência na ludoteca e no mais com relação igual eu falei, como tinha uma das professoras que ela tinha também esse grupo de alunos, de graduandos, que se quisessem, poderiam estar atuando como professores recuperadores, eu lembro que eu cheguei a atuar em algumas escolas lá do município. Eu e mais algumas colegas, nós íamos para poder dar aula de reforço no contra 
Libâneo e Pimenta (2011, p.55) afirmam que, na maioria dos cursos, o contato com a realidade escolar é vivenciado após o aluno receber a formação teórica, entretanto, "o caminho deve ser outro [...]”. Para eles, os alunos precisam ser logo inseridos no seu campo, a fim de conhecer melhor os sujeitos e as situações com as quais irão trabalhar. O contato com o campo profissional de atuação é condição sine qua non para um bom desempenho profissional. Na atualidade, o PIBID - Programa Institucional de Bolsa de Iniciação à Docência (BRASIL, 2010) tem essa função. Gatti (2014) aponta outros programas que fomentam a inserção de licenciandos no seu campo de atuação.

Para Pimenta e Lima (2012, p.45), “o estágio curricular é atividade teórica de conhecimento, fundamentação, diálogo e intervenção na realidade [...]”. Os depoimentos não revelaram a carga horária do estágio e nem como se dava o acompanhamento, mas seis sujeitos mencionaram que o estágio ocorreu ao final do curso, dois citaram que foi no início e treze realizaram o estágio na área em que se tornou especialista, exigência do Parecer CFE nº 252/69 que, na concepção de Bissolli da Silva (2006), deu-se em função de possibilitar, ao portador desse título profissional, uma vivência na especialidade em que atuará.

Em relação à pesquisa na formação dos pedagogos, os relatos indicaram que o estímulo e a participação em projetos de pesquisa não eram considerados, tal qual registrou Ludke (2012), indicando que tanto a prática quanto a formação para a pesquisa não têm sido consideradas relevantes pelos professores formadores que atuam nos cursos de Magistério e nas Licenciaturas. O incentivo à pesquisa e à iniciação científica deu-se apenas para seis entrevistados. Um dos seus fala sobre sua experiência com a pesquisa:

Como a gente tinha que fazer o projeto de pesquisa no final do curso, então, todos incentivavam muito essa questão da pesquisa, da gente buscar. [...] Eu achei muito interessante porque foi uma época que, ao mesmo tempo, é, que ela [a orientadora] me incentivou a pesquisar, a buscar informação em textos bem mais acadêmicos e, ao mesmo tempo em que a gente teve que ter um esforço muito grande, um esforço mental muito grande para escrever [...] eu levava os textos para ela, a gente revisava, a gente reescrevia, eu fazia entrevista também com os professores, no caso, lá na cidade. A gente também teve que passar por esse processo de selecionar professor, para fazer entrevista, convidar, gravar, transcrever a entrevista. Então, eu acho que foi uma experiência bem positiva, foi bem legal, bem interessante. (Pedagogo 12)

Sete entrevistados disseram não ter tido contato com a pesquisa durante o curso e dois relataram que pesquisavam apenas para fazer os trabalhos. Nesse último caso, como se verificou, tratava-se de pesquisa bibliográfica. Os relatos abaixo ilustram 
esse achado.

Eu acho que tinha que ter mais a questão da pesquisa, eu não fiz a pesquisa, a gente era muito do estágio, que era um campo da pesquisa, mas não era a pesquisa em si [...] (Pedagogo 11)

Nem teve e, assim, não me incentivava muito não, essa pesquisa, você ir a campo, você buscar, você ter informações. A pesquisa que se fala é campo, a pesquisa deles é só livro, estudo de casos, tudo nos livros, tudo nos livros, livro, livro, livro, trabalho em cima de trabalho e trabalho. Você fazer, construir, nada. (Pedagogo 13)

O estudo revela que faltou estimular a prática investigativa, por meio do desenvolvimento da pesquisa, o que propicia uma leitura da realidade na qual o sujeito está inserido e a reflexão sobre sua própria ação a partir do conhecimento de outras realidades. Esse fato pode estar vinculado à questão do locus formativo, o que já foi discutido ao apresentar o perfil dos protagonistas da pesquisa.

Para Alarcão (2001, p.12), "os futuros professores aprendem a investigar com os investigadores. A vivência em comunidades de aprendizagem marcadas pelo espírito de investigação constitui ambientes favoráveis ao desenvolvimento do espírito de pesquisa [...]”. Ao destacar a relevância da pesquisa para a formação e prática docente, Ludke (2012, p.51) declara que aquele que não tiver esse acesso terá "menos recursos para questionar devidamente sua prática e todo o contexto no qual ela se insere, o que o levaria em direção a uma profissionalidade autônoma e responsável”, já que a considera como "um recurso de desenvolvimento profissional".

Dentre os pontos fortes do curso estão: a experiência daqueles que tinham cursado o Magistério e, por isso, possuíam uma base formativa; a presença dos colegas que já atuavam, pois isso contribuía para fomentar o debate acerca das questões teóricas; realizar o estágio no início do curso e a obrigatoriedade de cursá-lo mesmo já sendo docente; a formação dos professores universitários; as habilitações e ter estudado Língua Portuguesa em todos os períodos.

[...] a minha experiência já de sala de aula ajudou muito, tanto que tinha colegas que não eram professoras. Eram colegas que tinham feito Administração, Contabilidade, cursos completamente diferentes. Então no grupo, era sempre falado assim, a gente com a experiência de "Fulana", o resto a gente vai fazendo. Então minha experiência sempre contava muito. (Pedagogo 3)

[...] essa possibilidade de você sair com essas quatro habilitações, isso também era legal. Porque às vezes eu não tenho vontade nenhuma de trabalhar com docência, eu acho que eu não tenho esse perfil, para alfabetizar. Mas aí, eu, nessa formação minha, eu tenho essa 
Pedagogos da SRE-OP: desvelando o perfil, as escolhas e a formação desses profissionais

possibilidade de dar mais ênfase para a supervisão e para a orientação ou então para a inspeção. (Pedagogo 8)

Como lacunas, os entrevistados destacaram o fato de o curso ter sido muito teórico, sendo que, para alguns, a teoria deveria ter sido mais articulada com a prática. Enfatizaram que parte da base de formação foi obtida no Magistério e um dos entrevistados destacou que as práticas voltavam-se mais para o trabalho do docente do que para o trabalho do especialista.

Eu senti muita dificuldade quando eu cheguei à prática. Eu senti muita dificuldade disso, de fazer essa relação [teoria x prática]. Eu tenho mais lembranças do curso de Magistério, de que é importante para mim, na minha prática, do que do curso de Pedagogia. A Didática, a Metodologia. (Pedagogo 9)

Talvez do meu Magistério tenha sido muito mais rico. Porque no Magistério nós tivemos a Metodologia da Alfabetização, Método Global, Método Silábico, Método Fônico, na Matemática trabalhar com o sistema de numeração, flanelógrafo, a gente construía tudo isso, quadro posicional, trabalho com conjunto, com barbante. Isso ficou mais no meu Magistério. A minha Pedagogia talvez seja mais sobre algo assim dos teóricos, a parte de conhecimento, de Piaget, mas muito na teoria. (Pedagogo 2)

Cruz (2011, p.73) afirma que a relação entre teoria e prática, nos cursos de Magistério e de Pedagogia, pode ser assim explicada: "no Curso Normal, predominou a ênfase na prática com 'muita’ teoria e, no Curso de Pedagogia, predominou a ênfase na teoria com ‘pouca’ prática.” Uma formação que articule teoria e prática é o caminho para alcançar uma prática pedagógica mais reflexiva.

Além das lacunas já descritas, foram citados ainda: o grande número de disciplinas do curso; a necessidade de se aprofundar em alguns conteúdos; a infraestrutura que influenciava a adoção de metodologias; o pouco apoio à pesquisa; a falta de oferta das atividades de extensão; a realização do estágio só ao final do curso.

O curso ele é muito amplo, então, assim, na prática mesmo quando você começa a trabalhar é, você começa a perceber as lacunas. Mas é igual, por exemplo, a questão que eu citei da dificuldade que o professorado tem com relação à leitura, ao processo de escrita, de identificação até das etapas, de qual etapa ali que a criança está. Então assim, eu lembro que quando eu comecei a trabalhar, que eu também precisava fazer essa identificação eu recorria ao meu material da graduação. Então eu acho que assim, a gente vê muita coisa e ao mesmo tempo você tem muito pouco tempo para poder, digamos assim, aprofundar. Então eu não conseguiria lhe dizer que faltou alguma coisa, eu acho que faltou mais tempo para poder aprofundar em tudo aquilo que a gente viu. 
(Pedagogo 12)

Agora, as carências, eu não sei bem, assim, eu acho que eu devia ter estudado mais LDB ou talvez quando eles propuseram o estudo eu não achei que fosse tão importante, os CBC, as Matrizes de Referência, tanta coisa que eu tinha que ter estudado e não estudei. [...] Eu acho que deficiência tenha sido isso, ter estudado mais esses instrumentos, por exemplo, pegar o CBC de ciência e ir a fundo, o que tenho que saber em ciências, pegar a Matriz de Referência do primeiro ao quinto ano, o que um menino de primeiro ano tem que saber, ir a fundo nisso, sabe? (Pedagogo 7)

Nos relatos apresentados pelos protagonistas da investigação, podemos encontrar contribuições relevantes para que formadores e instituições que ofertam esse curso possam repensar o processo de formação inicial do pedagogo.

\section{A formação continuada}

Por meio da LDB n 9394/96, foi outorgado ao poder público, das três esferas, a responsabilidade pela promoção da formação inicial, da continuada e da capacitação dos profissionais de magistério. Ao caracterizar a formação continuada, Gatti registra que:

[...] ora se restringe o significado da expressão aos limites de cursos estruturados e formalizados oferecidos após a graduação, ou após ingresso no exercício do magistério, ora ele é tomado de modo amplo e genérico, como compreendendo qualquer tipo de atividade que venha a contribuir para o desempenho profissional - horas de trabalho coletivo na escola, reuniões pedagógicas, trocas cotidianas com os pares, participação na gestão escolar, congressos, seminários, cursos de diversas naturezas e formatos, oferecidos pelas Secretarias de Educação ou outras instituições para pessoal em exercício nos sistemas de ensino, relações profissionais virtuais, processos diversos a distância (vídeo ou teleconferências, cursos via internet etc.), grupos de sensibilização profissional, enfim, tudo que possa oferecer ocasião de informação, reflexão, discussão e trocas que favoreçam o aprimoramento profissional, em qualquer de seus ângulos, em qualquer situação. (GATTI, 2008, p.57)

No contexto atual, há a necessidade de superar os modelos hegemônicos de formação e levar em consideração o protagonismo dos docentes ao propor as ações de formação. É preciso desenvolver essas ações de forma articulada, envolvendo os docentes desde a fase de concepção da proposta, visto que "[...] os processos de formação continuada que buscam modificar conceitos, atitudes e práticas não podem ignorar o que pensam e sabem os professores e as influências do ambiente sociocultural em que vivem e trabalham.” (GATTI; BARRETTO, 2009, p.231)

Os pedagogos relataram que se capacitam por meio da participação em cursos de 
curta duração, de especialização e participando da oferta de disciplina isolada do Mestrado, de eventos e congressos. Também se formam a partir da leitura, pesquisando, trocando ideias e experiências com outros profissionais, além de participarem de formações ofertadas aos docentes como o Pacto Nacional pela Alfabetização na Idade Certa (BRASIL, 2012).

Um profissional mencionou a existência de um setor de formação continuada institucionalizado na rede de ensino em que atua, todavia, a formação que é ofertada trabalha uma única temática com o pedagogo, gestor e professor. Essa rede também conta com o apoio de uma consultoria. Nas demais redes, existem a oferta de formações a partir de parcerias firmadas com a Universidade Federal de Ouro Preto e outros órgãos do governo estadual e federal, entretanto, nos relatos, fica explícito que não há uma formação específica para o pedagogo e que ela faz falta. Quando ocorrem encontros, eles têm um caráter mais informativo, voltados para a orientação legal.

Acho que essa falta de formação faz falta, muita falta [...]. Nos últimos anos, não está havendo nenhum [curso], nem reunião para troca de informação [...] (Pedagogo 6)

Não. Não tem. Eu sinto falta disso, que eu acho que tinha que investir mais na formação continuada. Tem assim, encontros de pedagogos até para discutir determinados assuntos, mas muito superficiais. É. Informação. É verdade, são momentos pontuais para tirar dúvidas, para tratar de um assunto específico, mas não assim curso voltado, não. (Pedagogo 14)

A Secretaria, numa época, mandava a gente para os congressos e pagavam. Parou também. Já parou. Se a gente quer fazer alguma coisa a gente que tem que pagar. É por conta própria. Particular. Agora tudo é do nosso bolso, você quer ir, tem que ser do nosso bolso. (Pedagogo 15)

Os dados que surgem dos depoimentos nos direcionam para três relevantes questões, que necessitam ser discutidas quando tratamos da formação continuada dos pedagogos: a inexistência de uma formação específica; a forma como esses profissionais têm desenvolvido sua formação continuada; a responsabilidade pela oferta da formação. Diante da inexistência de um programa sistematizado de formação continuada que busque atender às demandas desses profissionais, eles criam estratégias próprias e participam das ações voltadas para os docentes. Buscando formas próprias, eles assumem o protagonismo pela sua formação e se distanciam do modelo hegemônico que predominou há algum tempo, cujo participante era um mero receptor de conteúdos, a teoria era privilegiada em detrimento da prática e do contexto do participante. A inexistência de uma formação específica para esse profissional reitera que "a formação continuada é organizada com pouca sintonia com as necessidades dos professores e da 
escola.” (GATTI; BARRETO, 2009, p.221) e que, para os pedagogos que se encontram no exercício da coordenação pedagógica, são oferecidos cursos que tratam "da docência e prática dos professores, sendo raros os que oferecem formação específica para este profissional [...]" (PLACCO; SOUZA; ALMEIDA, 2012, p.9)

Enfim, o cenário evidenciado apresenta um indício de que o poder público da região não tem envidado esforços suficientes para garantir a formação continuada de todos os profissionais da educação, conforme está disposto em lei e, como diz Imbernón (2011, p.50), a formação permanente atua como um antídoto capaz de combater "práticas profissionais como a hierarquia, o sexismo, a proletarização, o individualismo, o pouco prestígio etc., e práticas sociais como a exclusão, a intolerância, etc.”

\section{Considerações Finais}

Mediante a elaboração deste estudo, organizado a partir dos marcos teóricos, foi possível delimitar a trajetória do curso de Pedagogia, no Brasil, e reconhecer as normativas legais que o constituíram até ele alcançar a configuração que apresenta na atualidade. Cada uma dessas modificações colaborou para o surgimento e a manutenção de críticas, dicotomias, debates, discussões, reflexões e pesquisas que, historicamente, envolveram o curso de Pedagogia, no Brasil. E, claro, essas questões não cessaram com a aprovação das últimas diretrizes curriculares, pelo contrário, mediante a aprovação das DCN, de 2006, novas questões se agregaram às antigas.

A pesquisa também possibilitou conhecer quem são os pedagogos que atuam nas instituições de ensino público da SRE-OP, explicitando o seu perfil, as escolhas que os conduziram ao curso de Pedagogia, o seu processo de formação inicial e como ocorre a formação continuada no âmbito de sua atuação profissional.

Os pedagogos da SRE-OP são os especialistas, formados na vigência do Parecer CFE $n^{0}$ 252/69, quando o curso de Pedagogia estava estruturado por habilitações. São, em sua maioria, mulheres que têm, na sua base de formação, o curso de Magistério, que foi o fator que mais influenciou a escolha pelo curso. Esses profissionais ocupam cargos distintos, estabelecidos em função do curso e da rede em que atuam, evidenciando a multiplicidade de denominações atribuídas aos profissionais formados por esse curso.

Ao desvelar o processo da formação inicial, os dados indicaram que: a formação varia em função do locus em que se realiza; a pesquisa é fundamental na formação profissional; existe a necessidade de propiciar outras formas de inserção dos licenciandos no seu campo de atuação, buscando extrapolar a forma tradicional que se dá por meio do estágio e é preciso encontrar um ponto de equilíbrio entre a formação teórica e prática, para que uma não sobressaia sobre a outra, já que se complementam e são primordiais. Os dados ainda destacaram algumas lacunas do curso que necessitam ser repensadas com vistas a garantir uma formação mais abrangente.

No que concerne à formação continuada, a pesquisa revelou que a forma como 
essas ações vêm ocorrendo não atende, totalmente, às demandas dos profissionais, já que, na literatura educacional, vem sendo evidenciada a necessidade de se considerar o protagonismo dos educadores na definição e no planejamento dessas ações de formação. Como se trata de profissionais que atuam na coordenação pedagógica e não na docência, as especificidades da ciência pedagógica, do cargo ocupado, do seu cotidiano e do contexto de trabalho precisam ser levadas em consideração.

Esta pesquisa também evidenciou a importância de se discutir a formação dos pedagogos, em razão das transformações que perpassaram o curso e que, ainda hoje, promovem mudanças na formação e nas atribuições desses profissionais, bem como no cotidiano das escolas. Como contribuições, acreditamos que a maior delas está relacionada à formação inicial dos licenciandos ao abordar aspectos inerentes à construção do conhecimento acerca do curso de Pedagogia, no Brasil, e ao processo formativo desse profissional. Sua relevância social reside no fato de trabalhar com pedagogos que estão no exercício da função e que, ao relatarem sobre suas trajetórias, trazem à tona questões relacionadas às suas escolhas, à profissão e ao contexto que vivenciam hoje. Para as instituições formadoras, tomar conhecimento dos pontos fortes e deficitários do curso pode constituir um indicador de avaliação para o que necessita ser aprimorado em sua IES e, dessa forma, contribuir para propor alterações no currículo e para uma melhor qualificação de seus egressos.

Ao finalizarmos este artigo, reconhecemos que o curso de Pedagogia mantém seu status de curso polêmico e continuará no cerne dos debates do meio educacional. Afirmamos que essa condição não se modificará, pois as discussões acerca desse curso estão longe de ser encerradas. Permanecemos entre velhas e novas questões.

\section{Referências}

AGUIAR, M. A. S. et al. Diretrizes curriculares do curso de pedagogia no Brasil: disputas de projetos no campo da formação profissional da educação. Educação \& Sociedade, Campinas, v. 27, n. 96 - Especial, p. 819-842, out. 2006. Disponível em:<http://www.scielo.br/pdf/es/v27n96/ a10v2796.pdf>. Acesso em: 13 out. 2011.

; MELO, M. M. O. Pedagogia e Diretrizes Curriculares: Polêmicas e Controvérsias. Linhas Críticas, Brasília, v. 11, n. 20, p. 119-138, jan./jun. 2005. Disponível em: <http://www.redalyc.org/ pdf/1935/193520514008.pdf>. Acesso em: 02 fev. 2014.

ALARCÃO, I. Professor-investigador: Que sentido? Que formação? Cadernos de Formação de Professores, No 1, pp. 21-30, 2001. Disponível em: <http://www.educ. fc.ul.pt/docentes/jponte/sd/ textos/alarcao01.pdf>. Acesso em: 16 jan. 2016. 
BARDIN, L. Análise de Conteúdo. São Paulo: Edições 70, 2011.

BOGDAN, R. C.; BIKLEN, S. K. Investigação Qualitativa em Educação - uma introdução à teoria e aos métodos. Porto: Porto Editora. 1994.

BRASIL. Conselho Federal de Educação. Parecer n² 251/62. Fixa o currículo mínimo e a duração do Curso de Pedagogia. Relator: Valnir Chagas. In: Documenta. $n^{\circ} 11$. Jan.-Fev. 1963. p.59-66.

. Conselho Federal de Educação. Parecer n 252/69. Fixa os mínimos de conteúdo e duração a serem observados na organização do curso de Pedagogia. Relator: Valnir Chagas. In: Documenta. nº 100. Abr. 1969. p.101-139.

. Conselho Nacional de Educação. Parecer CNE/CP nº 03/2006, de 21 de fevereiro de 2006. Reexame do Parecer CNE/CP n ${ }^{0} 5 / 2005$, que trata das Diretrizes Curriculares Nacionais para o Curso de Pedagogia. Diário Oficial da União, Brasília, 11 abr. 2006b. Disponível em: <http://portal.mec.gov.br/cne/arquivos/pdf/pcp003_06. pdf>. Acesso em 27 dez. 2013.

. Conselho Nacional de Educação. Parecer CNE/CP nº 05/2005, de 13 de dezembro de 2005. Diretrizes Curriculares Nacionais para o Curso de Pedagogia. Diário Oficial da União, Brasília, 15 maio 2006. Disponível em: <http://portal.mec. gov.br/cne/arquivos/pdf/pcp05_05.pdf>. Acesso em 26 dez. 2013.

. Conselho Nacional de Educação. Resolução no 1/2006, de 15 de maio de 2006. Institui Diretrizes Curriculares Nacionais para o Curso de Graduação em Pedagogia, Licenciatura. Diário Oficial da União, Brasília, 16 maio 2006a, Seção 1, p. 11. Disponível em: <http://portal.mec.gov.br/cne/arquivos/pdf/rcp01_06.pdf>. Acesso em: $21 \mathrm{dez} .2013$.

. Decreto ${ }^{0} 19.851$, de 11 de abril de 1931. Dispõe que o ensino superior no Brasil obedecerá, de preferência, ao sistema universitário, podendo ainda ser ministrado em institutos isolados, e que a organização técnica e administrativa das universidades é instituída no presente Decreto, regendo-se os institutos isolados pelos respectivos regulamentos, observados os dispositivos do seguinte Estatuto das Universidades Brasileiras. Diário Oficial da União, Rio de Janeiro, RJ, 15 abr. 1931a. Disponível em: <http://www2.camara.leg.br/legin/fed/decret/1930-1939/decreto-19851-11-abril1931-505837-publicacaooriginal-1-pe.html>. Acesso em: 20 dez. 2013.

. Decreto ${ }^{\circ}$ 19.852, de 11 de abril de 1931. Dispõe sobre a organização da Universidade do Rio de Janeiro. Diário Oficial da União, Rio de Janeiro, RJ, 04 jun. 1931b. Disponível em: <http://www2.camara.gov.br/legin/fed/decret/1930-1939/ 
decreto-19852-11-abril-1931-510363-republicacao-85622-pe.html>. Acesso em: 20 dez. 2013.

. Decreto $n^{\circ} 22.579$, de 27 de março de 1933. Regula o funcionamento das universidades brasileiras em quanto não fôr consolidada a legislação sôbre ensino superior. Diário Oficial da União, Rio de Janeiro, RJ, 28 mar. 1933. Disponível em: $<$ http://www2.camara.leg.br/legin/fed/ decret/1930-1939/decreto-22579-27-marco1933-504261-publicacaooriginal-1-pe.html>. Acesso em: 20 dez. 2013.

. Decreto $n^{0} 7.219$, de 24 de junho de 2010. Dispõe sobre o Programa Institucional de Bolsa de Iniciação à Docência - PIBID e dá outras providências. Diário Oficial da União, Brasília, 25 jun. 2010. Disponível em: <http://www2.camara.leg.br/legin/ fed/decret/2010/decreto-7219-24-junho-2010-606872-publicacaooriginal-127693-pe. html >. Acesso em: 11 jul. 2015.

. Decreto-Lei no 1190, de 04 de abril de 1939. Dá organização à Faculdade Nacional de Filosofia. Diário Oficial da União, Rio de Janeiro, RJ, 06 abr. 1939. Disponível em: <http://www2.camara.leg.br/legin/fed/declei/1930-1939/decreto-lei1190-4-abril-1939-349241-publicacaooriginal-1-pe.html>. Acesso em: 08 set. 2013.

. Lei no 452 de, 05 de julho de 1937. Organiza a Universidade do Brasil. Diário Oficial da União, Rio de Janeiro, RJ, 10 jul. 1937. Disponível em: <http://www2. camara.leg.br/legin/fed/lei/ 1930-1939/lei-452-5-julho-1937-398060-publicacao original-1-pl.html. Acesso em: 21 dez. 2013.

. Lei $n^{\circ}$ 5.540, de 28 de novembro de 1968. Fixa normas de organização e funcionamento de ensino superior e sua articulação com a escola média e dá outras providências. Diário Oficial da União, Brasília, 29 nov. 1968. Disponível em: http:// www2.camara.leg.br/legin/fed/lei/1960-1969/lei-5540-28-novembro-1968-359201norma-pl.html. Acesso em: 23 dez. 2013.

. Lei $n^{\circ}$ 5.692, de 11 de agosto de 1971. Fixa diretrizes e bases para o ensino de $1^{\circ}$ e $2^{\circ}$ graus, e dá outras providências. Diário Oficial da União, Brasília, 12 ago. 1971. Disponível em: http://www2.camara.leg.br/legin/fed/lei/1970-1979/lei-569211-agosto-1971-357752-publicacaooriginal-1-pl.html>. Acesso em 23 dez. 2013.

. Lei n. 9.394, de 20 de dezembro de 1996. Dispõe sobre as Diretrizes e Bases da Educação Nacional. Diário Oficial da União, Brasília, DF, 23 dez. 1996. Disponível em: <http://www2.camara.leg.br/legin/fed/lei/1996/lei-9394-20-dezembro-1996362578-publicacaoorigi nal-1-pl.html>. Acesso em: 23 dez. 2013.

. Ministério da Educação e Cultura. Portaria nº 867/12. Brasília, 2012. Institui 
o Pacto Nacional pela Alfabetização na Idade Certa e as ações do Pacto e define suas diretrizes gerais. Disponível em: <http://pacto.mec.gov.br/documentos-importantes $>$. Acesso em: 13 jul. 2015.

BRZEZINSKI, I. Pedagogo: delineando identidade (s). Revista UFG. Goiânia, Ano XIII, v.10, p. 120-132, jul. 2011. Disponível em: <http://www.proec.ufg.br/revista_ufg/ Revista\%20UFG\% 20Julho\%20\%202011/arquivos_pdf/iria_brzezinski.pdf > . Acesso em: 24 mar. 2014.

CASTRO, M. A formação de professores e gestores para os anos iniciais da educação básica: das origens às diretrizes curriculares nacionais. RBPAE, Goiânia, v.23, n.2, p. 199-227,maio/ago. 2007. Disponível em: <http://seer.ufrgs.br/rbpae/article/ view/19126>. Acesso em:01 dez. 2014.

CRUZ, G. B. 70 anos do curso de Pedagogia no Brasil: uma análise a partir da visão de dezessete pedagogos primordiais. Educação \& Sociedade, Campinas, v. 30, n. 109, p. 1187-1205, set./dez. 2009. Disponível em: <http://www.scielo.br/pdf/es/v30n109/ v30n109a13.pdf>.Acesso em: 27 mar. 2014.

. Curso de Pedagogia no Brasil: história e formação com pedagogos primordiais. Rio de Janeiro: Wak Editora, 2011.

EVANGELISTA, O.; TRICHES, J. Diretrizes curriculares nacionais para o curso de pedagogia: docência, gestão e pesquisa. In: VII Seminário de Pesquisa em Educação da Região Sul, 2008, Itajaí. p. 1-17. Disponível em: <http://www.portalanpedsul.com.br/ admin/uploads/2008/Politicas_publicas_e_Gestao_educacional/Trabalho/07_22_29_ DIRETR 1.PDF>. Acesso em: 07 out. 2014.

FRANCO, M. A. S. Pedagogia como ciência da educação. 2a . ed. São Paulo: Cortez, 2008.

..:; LIBÂNEO, J. C.; PIMENTA, S. G. Elementos para a formulação de Diretrizes Curriculares para o Curso de Pedagogia. Cadernos de Pesquisa, v. 37, n. 130, p. 63-97, jan./abr. 2007. Disponível em: http://www.scielo.br/pdf/cp/v37n130/05.pdf>. Acesso em: 21 jun. 2014.

GATTI, B. A. Análise das políticas públicas para formação continuada no Brasil, na última década. Revista Brasileira de Educação, Rio de Janeiro, v. 13, n. 37, p. 5770, jan./abr. 2008. Disponível em: http://www.scielo.br/pdf/rbedu/v13n37/06.pdf>. Acesso em: 19 jul. 2014.

. A formação inicial de professores para a educação básica: as licenciaturas. 
Revista USP, São Paulo, n. 100, p. 33-46, dez./jan./fev. 2013-2014. Disponível em:<http://www.revistas.usp.br/revusp/article/view/76164>. Acesso em: 03 mar. 2015.

(Coord.); BARRETTO, E. S. S. Professores do Brasil: impasses e desafios. Brasília: UNESCO, 2009. Disponível em: <http://unesdoc.unesco.org/ images/0018/001846/184682por.pdf>. Acesso em: 07 jun. 2013.

IMBERNÓN, F. Formação docente e profissional: formar-se para a mudança e a incerteza. 9a. ed. São Paulo: Cortez, 2011.

LEITE, Y. U. F.; LIMA, V. M. M. Cursos de Pedagogia no Brasil: o que dizem os dados doINEP/MEC? Ensino Em-Revista, Uberlândia, v.17, n.1, p. 69-93, jan./jun. 2010. Disponível em: <http://www.seer.ufu.br/index.php/emrevista/article/view/8185/5197>. Acesso em: 03mar. 2015.

LIBÂNEO, José C. Ainda as perguntas: o que é pedagogia, quem é o pedagogo, o que deve ser o curso de Pedagogia. In: PIMENTA, S. G. (Org.) Pedagogia e Pedagogos: caminhos e perspectivas. $3^{\text {a }}$. ed. São Paulo: Cortez, 2011. cap. 2, p. 63-100.

. A pedagogia em questão: entrevista com José Carlos Libâneo. In: Olhar de professor, Ponta Grossa, v. 10, p.11-33, 2007. Disponível em <http://www.uepg. br/olhardeprofessor > Acesso em 14 fev. 2015.

; PIMENTA, S. G. Formação de profissionais da educação: visão crítica e perspectiva de mudança. In: PIMENTA, S. G. (Org.) Pedagogia e Pedagogos: caminhos e perspectivas. $3^{\mathrm{a}}$. ed. São Paulo: Cortez, 2011. cap. 1, p. 15-61.

LIMA, E. F. Formação de professores - passado, presente e futuro: o curso de Pedagogia. In: MACIEL, L. S. B.; SHIGUNOV NETO, A. (Orgs). Formação de Professores Passado, Presente e Futuro. São Paulo: Cortez, 2004.

LUDKE, M. A complexa relação entre o professor e a pesquisa. In: ANDRÉ, M. E. D. A. (Org.). O papel da pesquisa na formação e na prática dos professores. $12^{\mathrm{a}}$. ed. Campinas: Papirus, 2012. cap. 2, p. 27-54.

PIMENTA, S. G.; LIMA, M. S. L. Estágio e Docência. 7ª. ed. São Paulo: Cortez, 2012.

PINHEIRO, G. C. G.; ROMANOWSKI, J. P. Curso de Pedagogia: formação do professor da Educação Infantil e dos anos séries iniciais do Ensino Fundamental. Formação Docente, Belo Horizonte, v. 02, n. 03, p. 136-151, ago./dez. 2010. Disponível em:http://formacaodocente. autenticaeditora.com.br/artigo/exibir/8/24/1>. Acesso em: 03 mar.2015. 
PLACCO, V. M. N. S.; SOUZA, V. L. T.; ALMEIDA, L. R. Proposição de Políticas Públicas quanto à formação de Coordenadores Pedagógicos, Formadores de Professores. In: Encontro Nacional de Didática e Prática de Ensino, XVI, 2012, Campinas. Disponível em: < http://www.infoteca.inf.br/endipe/smarty/templates/arquivos_ template/upload_arquivos/acervo/docs/0057s.pdf>. Acesso em: 30 abr. 2014.

SARAIVA, A. C. L. C.; FERENC, A. V. F. A escolha profissional do curso de pedagogia: análise das representações sociais de discentes. In: Reunião Nacional da Associação Nacional de Pós-Graduação e Pesquisa em Educação, XXXIII, 2010, Caxambu. Disponível em: <http://33reuniao.anped.org.br/33encontro/app/webroot/files/file/ Trabalhos\%20em\%20PDF/GT08-6350--Int.pdf>. Acesso em: 08 jul. 2015.

SAVIANI, D. A pedagogia no Brasil: história e teoria. Campinas: Autores Associados, 2008.

. O espaço acadêmico da Pedagogia no Brasil: perspectiva histórica. Paidéia. Ribeirão Preto, v. 14, n. 28, p. 113 -124, 2004. Disponível em: <http://www.scielo. br/pdf/paideia/v14n28/02.pdf >. Acesso em: 29 nov. 2014.

SCHEIBE, L.; Diretrizes Curriculares para o Curso de Pedagogia: Trajetória Longa e Inconclusa. Cadernos de Pesquisa, São Paulo, v. 37, n. 130, p. 43-62, jan./abr. 2007. Disponível em: <http://www.scielo.br/pdf/cp/v37n130/04.pdf>. Acesso em 27 dez. 2013.

; AGUIAR, M. A. Formação de profissionais da educação no Brasil: o curso de pedagogia em questão. Educação \& Sociedade, Campinas, v. 68, p. 220-238, dez. 1999. Disponível em: <http://www.scielo.br/pdf/es/v20n68/a12v2068.pdf>. Acesso em: 13 out. 2011.

SILVA, C. S. B. Curso de pedagogia no Brasil - história e identidade. $3^{\text {a }}$. ed. Campinas: Autores Associados, 2006.

. Curso de Pedagogia no Brasil: uma questão em aberto. In: PIMENTA, S. G. (Org.) Pedagogia e Pedagogos: caminhos e perspectivas. $3^{\text {a }}$. ed. São Paulo: Cortez, 2011. cap. 4, p.131-154.

Recebido em: 22/02/2018

Aprovado em: 27/02/2019 